\title{
Pengaruh Tangible, Empathy Dan Assurance Terhadap Keputusan Pembelian Pada PT. Raden Auto Jakarta
}

\author{
Hendry Syahrial*
}

M.Rizan**

*Universitas Jayabaya

**Universitas Negeri Jakarta

ARTICLE INFO ABSTRACT

Keywords:

Tangible, empathy, assurance decisions to buy, PT Raden Auto

Corresponding Author:

dr_rizan@yahoo.com

Manajerial

Volume 9 Nomor 1

Mei-Oktober 2015

ISSN. 1907- 4832

hh. $41-50$
The objectives of this study were determining the effect of tangibles, empathy, and assurance on the decision to buy at PT Raden auto, Jakarta. This study uses a quantitative approach to data collection techniques using questionnaires. The populations used in this study are the consumer at PT. Raden Auto Jakarta, while the sample using purposive sampling technique, which determines the sample by chance, in order to obtain the total sample of 100 people. The results showed that the tangibles, empathy, and assurance were predicted by decision to buy. In other words, learning strategies has been a role in increasing tangibles, empathy, and assurance customers in the PT Raden Auto, Jakarta. The results proved that decision to buy was simultaneous affected by tangible, empathy, and asssurance.

Tujuan dari penelitian ini adalah untuk menguji secara empiris pengaruh antara emphaty, tangible, dan assurance terhadap keputusan pembelian di PT Raden auto, Jakarta. Penelitian ini menggunakan pendekatan kuantitatif dengan teknik pengumpulan data menggunakan kuesioner. Populasi yang digunakan dalam penelitian ini adalah konsumen di PT. Raden Auto Jakarta, sedangkan sampel menggunakan teknik purposive sampling, untuk menentukan sampel sebesar 100 orang. Hasil penelitian menunjukkan bahwa tangible, emphaty dan assurance yang diprediksi memengaruhi keputusan pembelian. Dengan kata lain, tangible, emphaty dan assurance telah berperan dalam meningkatkan keputusan pembelian pelanggan di PT Raden Auto, Jakarta. Hasil penelitian membuktikan bahwa keputusan pembelian dipengaruhi secara simultan oleh tangible, emphaty, dan assurance. 


\section{Pendahuluan}

Dewasa ini, sektor jasa mempunyai peran yang semakin besar, baik sebagai penyokong perekonomian maupun sebagai penyedia kesempatan kerja di Indonesia. Selain mempunyai peran penting sebagai barang konsumsi, jasa juga berperan sebagai kontributor bagi sektor produksi pada barang yang dapat diperdagangkan. Menurut laporan yang dirilis oleh International Labor Organization 2012, sejak tahun 2000-2010 terjadi pertumbuhan nilai tambah dan lapangan pekerjaan di sektor jasa Indonesia yang jauh lebih cepat daripada sektor-sektor utama lain seperti pertanian, manufaktur, pertambangan dan utilitas. Hanya dalam waktu satu dekade itu pula, kontribusi jasa terhadap PDB Indonesia meningkat dari $44 \%$ menjadi $52 \%$.

Berangkat dari hal tersebut, perusahaan jasa harus semakin fokus pada pengembangan merek jasa untuk memastikan sektor jasa semakin berkembang sebagai salah satu penggerak perekomian. Dengan semakin populernya service dominant logic (Vargo dan Lusch, 2004) yang fokus kepada proses penambahan nilai terhadap konsumen akan menciptakan pengalaman konsumen, seperti juga yang diungkapkan oleh Berry (2000). Dengan perspektif ini, merek memiliki peran yang semakin luas dimana merek tersebut tidak hanya berurusan dengan konsumen akhir, tetapi juga dengan perusahaan, karyawan sendiri, dan pemangku kepentingan.

Brodie, et al., (2008) menyebutkan perspektif dari merek ini sebagai merek jasa. Oleh sebab itu, diperlukan rasa percaya yang terbangun antara pelanggan dan penyedia layanan jasa. Dalam penelitian ini, dipilih penggunaan industri jasa otomotif khususnya mobil bekas karena industri tersebut memiliki peningkatan yang pesat. Sebagai salah satu industri yang agresif dalam pengembangan strategi komunikasi pemasaran dengan titik berat pada kualitas pelayanan, sehingga industri ini terus berkembang. Menurut laporan Business Monitor International (2012) bahwa industri mobil bekas diperkirakan akan terus meningkat dilihat dari prediksi jumlah penduduk pada tahun 2014 diperkirakan naik. Hal ini ditandai dengan terus bertambahnya kuantitas kendaraan yang dimiliki masyarakat. Disamping itu belum adanya kebijakan pemerintah yang membatasi tahun kendaraan roda empat yang layak jalan, menjadi pemicu pasar mobil bekas di Indonesia berkembang sangat pesat. Tahun 2000 merupakan tonggak munculnya pedagang-pedagang mobil bekas. Raden Auto merupakan perusahaan jasa bergerak di bidang bisnis mobil bekas sudah 14 tahun mengelola mobil bekas segala merk.
Menghadapi persaingan ketat di bisnis mobil bekas, para manajer mengeluh tentang kesulitan untuk menekan biaya dan menghasilkan laba, mencari karyawan terlatih yang memiliki motivasi, dan untuk memuaskan pelanggan. Perusahaan bergantung pada interaksi langsung dan pribadi antara pelanggan dan karyawan perusahaan. Sifat interaksi ini sangat mempengaruhi persepsi pelanggan terhadap kualitas pelayanan. Pelanggan sering menilai kualitas pelayanan yang mereka terima berdasarkan penilaian terhadap orang-orang yang menyediakan pelayanan tersebut. Sehingga dibutuhkan layanan yang lebih agar pelanggan tetap loyal dan setiap mereka akan membeli kendaraan bekas yang selalu ada dalam pikiran mereka adalah membeli pada PT Raden Auto.

Selain itu adanya kebijakan untuk memperketat uang muka pembiayaan yang dikeluarkan oleh pemerintah, Kementerian Keuangan menerbitkan Peraturan Menteri Keuangan (PMK) Nomor 220/PMK 010/2012 tentang Perubahan atas Peraturan Menteri Keuangan Nomor 43/PMK 010/2012 tentang Uang Muka Pembiayaan Konsumen untuk Kendaraan Bermotor pada Perusahaan Pembiayaan dan kebijakan memperketat uang muka pembiayaan juga dikeluarkan oleh Bank Indonesia dalam Surat Edaran Bank Indonesia No.14/10/DPNP tanggal 15 Maret 2012 tentang Penerapan Manajemen Risiko pada Bank yang melakukan Pemberian Kredit Pemilikan Rumah dan Kredit Kendaraan Bermotor, yang ditetapkan bagi roda empat atau lebih untuk tujuan produktif paling rendah 20 persen dan bagi kendaraan bermotor roda empat atau lebih yang digunakan untuk tujuan non produktif paling rendah 25 persen. Hal ini membuat penjualan kendaraan bekas yang pembiayaannya melalui kredit agak sedikit mengalami penurunan. Padahal masih banyak pelanggan yang mampu mencicil kendaraannya walaupun dengan uang muka yang rendah atau dibawah 20-25 persen. Akibat dari kebijakan pemerintah tersebut, Raden Auto selalu melakukan koreksi harga jual kendaraan setiap saat.

Kecenderungan pelanggan sangat kuatir untuk membeli kendaraan bekas sangatlah wajar. Perusahaan harus membekali pelanggan dengan informasi yang lengkap. Semakin tinggi tingkat kesulitan pelanggan dalam mengevaluasi produk sebelum melakukan pembelian, semakin tinggi persepsi resiko yang berkaitan dengan keputusan tersebut. Pelanggan terkadang kurang terbuka untuk menanyakan perihal mobil bekas ke sumber yang kompeten, misalnya ke Raden Auto Mereka sangat yakin dengan informasi yang didapat melalui internet atau pun 
sumber-sumber yang diragukan keakuratannya seperti, calo-calo mobil bekas, mekanik mobil, dan lain-lain.

Ketika pelanggan membeli kendaraan bekas, mereka membandingkan kendaraan tersebut dengan harga yang mereka pahami. Mereka membayar mahal selain karena kendaraan tersebut bagus, tetapi mereka membayar mahal untuk menghemat waktu mengurangi apa yang mereka perlukan, dan memperoleh kenyamanan yang lebih tinggi. Namun, karena tidak semua pelanggan bersedia (atau mampu) membayar lebih mahal, perusahan terkadang menciptakan nilai yang terkandung di dalam penjualan kendaraan bekas. Kajian strategi pemasaran sangat penting adalah menganalisis perilaku konsumen untuk strategy targeting dan positioning-nya. Konsep pemasaran modern orientasinya pada kebutuhan dan keinginan konsumen. Langkah pertama dari strategi ini memahami keinginan, kebutuhan dan selera konsumen (customer is king). Jika industri mobil bekas ingin tetap eksis di pasar otomotif, maka harus tetap konsisten dengan strategi tersebut.

Namun demikian di sisi lain, berkembangnya industri mobil bekas juga memberikan ruang ekspansi yang besar bagi perusahaan sejenis yang ada, dan sangatlah wajar bila perusahaan mobil bekas dengan positioning low cost semakin berkembang. Hal ini dikarenakan struktur demografis masyarakat Indonesia yang mengalami pertumbuhan paling cepat pada golongan menengah yang mencapai $51 \%$. Biaya pembelian mobil bekas yang relatif terjangkau tersebut dapat menjadi solusi yang tepat bagi kalangan menengah ke untuk turut menikmati memiliki sebuah kendaraan sebagai alat transportasi mereka.

Konsumen dapat dengan mudah membuat perbandingan antara produk atau jasa alternatif untuk membuat keputusan pembelian (Bolton et al., 2014). Berbeda dengan pendapat Sproles dan Kendall (Shah et al., 2012) bahwa gaya pengambilan keputusan konsumen adalah orientasi mental yang mencirikan pendekatan konsumen untuk membuat pilihan. Dalam melakukan keputusan pembelian, konsumen menjalankan pola pembelian di masa lalu (misalnya loyalitas merek atau kebiasaan membeli) untuk produk jenis tertentu (Terrell, 2002). Menurut Bearman dan Evans (2002), terdapat tiga tahapan dalam menumbuhkan keputusan membeli, yaitu: (1) Rangsangan, terjadi saat suatu keinginan mencapai daerah syaraf penerimaan indera seseorang. Misalnya: ketika seseorang melihat atau mendengar kegiatan yang inovatif dilakukan oleh suatu perusahaan mo- bil. (2) Kesadaran, untuk dapat menjadi perhatian atas kesadaran seseorang maka rangsangan tersebut harus dapat menggetarkan syaraf indera dan menimbulkan respon langsung atau sensasi-sensasi pada otak. Misalnya ketika seseorang merasa tertarik untuk lebih mengetahui lebih jauh mengenai kegiatan yang dilakukan perusahaan tersebut. (3) Pencarian informasi yang dibagi dalam: (a) informasi intern, bersumber dari ingatan konsumen untuk memilih barang atau jasa yang memuaskannya. (b) informasi ekstern, informasi yang berasal dari iklan, melalui kawan, ataupun dari media massa. (c) memastikan sifat yang khas dari setiap pilihan yang ada, pada tahap ini konsumen mengumpulkan informasi yang berhubungan dengan ciri dari setiap pilihan, setelah itu baru konsumen memutuskan barang/jasa yang akan dibelinya. (d) pemilihan alternatif, setelah informasi yang berkaitan dengan produk yang diinginkan telah diperoleh, maka konsumen melakukan penelitian akan alternatif-alternatif yang ada.

Niat untuk pembelian adalah jenis keputusan yang mempelajari alasan pelanggan membeli sebuah merek tertentu. Porter (Shah et al., 2012) menguraikan fokus utama dari niat pelanggan untuk membeli merek bukan hanya disebabkan oleh merek yang sama, tetapi oleh pilihan merek yang dipertimbangkan pada merek lain. Lain halnya dengan pendapat Bachler (2004) menjelaskan jenis pelanggan setia yang melakukan keputusan pembelian tanpa mempertimbangkan harga dan menunjukkan loyalitas mereka dengan menyarankan rekomendasi positif kepada perusahaan dan melakukan investasi untuk menunjukkan kepercayaan mereka terhadap merek yang dibeli. Menurut Rajagopal (2006) dalam situasi seperti ini, pelanggan harus bergantung hanya pada atribut ekstrinsik produk, sehingga dalam melakukan keputusan pembelian mengandalkan pada kemandirian individu secara efektif untuk menemukan pendapatan saat ini dan masa depan (Redmond, 2000).

Salah satu persyaratan utama dalam pengembangan organisasi bisnis adalah perlu mempertimbangkan pelanggan sebagai tujuan utama mereka dan kegiatan (Pourkiani, 2014). Menurut Katz (Sutisna, 2002) mengemukakan empat fungsi dari sikap, sebagai berikut: (1) Fungsi utilitarian/the utilitarian function. (2) Fungsi Mempertahankan ego/the ego-defensive function. (3) Fungsi ekspresi nilai/the value-expressive function (4) Fungsi pengetahuan/the knowledge function. Porter (Shah et al., 2012) menjelaskan bahwa perilaku pelanggan perilaku dalam pembelian juga 
tergantung pada tingkat persaingan yang ada dalam industri.

Pemasaran merupakan proses di mana perusahaan menciptakan nilai bagi pelanggan dan membangun hubungan yang kuat dengan pelanggan dengan tujuan untuk menangkap nilai dari pelanggan sebagai imbalannya (Kotler dan Armstrong, 2008). Para peneliti telah mencatat bahwa sangat penting untuk melihat lebih dekat konsumen mengembangkan hubungan atau interaksi dengan merek dan dapat membentuk komunitas merek dalam kehidupan pribadi mereka sendiri (Esch et al., 2006). Pemasaran merupakan suatu sistem keseluruhan dari kegiatan-kegiatan bisnis yang ditujukan untuk merencanakan, menentukan harga, mempromosikan dan mendistribusikan barang dan jasa yang memuaskan kebutuhan baik kepada pembeli yang ada maupun pembeli potensial (Swastha, 2000).

Konsep pemasaran (marketing concept) berpandangan bahwa kunci untuk mewujudkan tujuan organisasi terletak pada kemampuan organisasi dalam menciptakan, memberikan dan mengkomunikasikan nilai pelanggan (costumer value) kepada pasar sasarannya secara lebih efektif dibandingkan pada pesaing (Tjiptono, 2008) dalam mendapatkan kualitas yang baik.

Kualitas yang baik merupakan salah satu kunci sukses untuk mempertahankan produk dan layanan mereka. Namun, menjaga kualitas yang diinginkan untuk produk dan layanan bukanlah tugas yang mudah karena peningkatan persaingan telah menyebabkan banyak yang mencari keuntungan dengan mengabaikan kualitas. Oleh karena itu, penting untuk menemukan cara-cara yang sesuai untuk mempertahankan kualitas layanan dengan tujuan yang berbeda seperti retensi pelanggan (Namin, et al., 2012). Manajer perusahaan menyadari bahwa kualitas tinggi akan mengakibatkan kinerja yang lebih baik dan memiliki keunggulan seperti efisiensi keuangan, loyalitas pelanggan, memenuhi kebutuhan pelanggan, pertumbuhan pangsa pasar, dan produktivitas organisasi (Ghanbarpour et al., 2012 dan Theodorakis et al., 2013)

Persaingan yang ketat menyebabkan kualitas layanan menjadi faktor kunci bagi keberhasilan dan kelangsungan hidup organisasi (Pourkiani et al., 2014). Kualitas layanan disebut abstrak karena tiga fitur unik untuk layanan: tdk dpt dipahami, heterogenitas dan ketidakterpisahan produksi dan konsumsi (Patel dan Amrita, 2014). Kualitas pelayanan sebagai faktor yang paling penting dalam menentukan keberhasilan organisasi di lingkungan yang kompetitif. Setiap penurunan kepuasan pelanggan karena buruknya kualitas layanan menjadi alasan kurang baiknya organisasi. Pelanggan terhadap standar pelayanan dan tren kompetitif menjadi harapan untuk memperbaiki kualitas pelayanan (Karimi et al., 2009). Menurut Wykof (Arief, 2006) kualitas pelayanan adalah tingkat keunggulan yang diharapkan dan pengendalian atas tingkat keunggulan tersebut untuk memenuhi keinginan pelanggan. Kualitas pelayanan adalah faktor yang menentukan tingkat keberhasilan dan kualitas perusahaan dimana kemampuan perusahaan dalam memberikan pelayanan yang berkualitas kepada konsumen dan sebagai strategi perusahaan untuk mempertahankan diri dan mencapai kesuksesan dalam menghadapi persaingan (Lupiyoadi, 2008). Definisi kualitas pelayanan berpusat pada tingkat perbedaan dalam pemenuhan kebutuhan dan keinginan pelanggan serta penyampaian untuk mengimbangi persepsi dan harapan pelanggan terhadap pelayanan (Simamora, 2003; Pourkiani et al., 2014).

Kualitas pelayanan adalah salah satu atribut penting dari penyedia layanan karena mereka menganggap pengukuran kualitas pelayanan dari perspektif konsumen sebagai prioritas. Kualitas layanan merupakan faktor yang sangat diperlukan untuk kepuasan pelanggan, pengurangan biaya, loyalitas pelanggan, hubungan pelanggan dan retensi, profitabilitas dan sebagainya (Aghdaie dan Faghani, 2012). Sedangkan menurut Ehsani, et al., (2014) kualitas adalah salah satu kriteria yang paling penting untuk mengevaluasi layanan. Ini adalah bagian dari konsep yang luas dan berbeda dari komitmen organisasi untuk kualitas (Bahrain et al., 2009) Menurut Umar (2005) pengukuran terhadap kualitas pelayanan dinyatakan dalam lima dimensi kualitas pelayanan jasa, yaitu kehandalan (reliability), bukti fisik (tangible), daya tangkap (responsiveness), jaminan (assurance), dan empati (empathy).

Seyyed dan Kimasi (2005) menguraikan kelima unsur tersebut, yaitu: (1) tangibles merupakan faktor yang mengacu pada kondisi fisik, dekorasi atau tata letak, penampilan di lokasi pelayanan, penampilan staf dan peralatan modern. Indikator yang digunakan untuk mengukur faktor-faktor yang nyata termasuk peralatan modern, penampilan staf yang bersih dan rapi, fasilitas fisik serta tampilan yang menarik. (2) Reliability menggambarkan sejauh mana layanan dapat dipercaya. Reputasi organisasi digambarkan melalui perilaku karyawan dalam berkontribusi bagi perusahaan. Dimensi ini berkaitan dengan pekerjaan konsumen pada waktu, keingin- 
an untuk memecahkan masalah pelanggan, meminimalisir kesalahan dalam melaksanakan pekerjaan dan memberikan kesan positif melalui ketepatan pelayanan di pertemuan pertama. (3) Responsiveness didefinisikan sebagai kemampuan untuk menangani keluhan dan meningkatkan layanan secara efektif. Indikator yang digunakan untuk mengukur respon waktu, tanggap terhadap pelanggan dan untuk membantu pelanggan memecahkan masalah. (4) Assurance merupakan kemampuan untuk menjamin dalam layanan. Hal-hal yang diukur adalah pengetahuan, kesopanan dalam berurusan dengan konsumen, kepercayaan pelanggan dan keamanan melalui perilaku karyawan. (5) Empathy sebagai upaya melibatkan diri untuk mencoba memahami kebutuhan spesifik dan tuntutan pelanggan, perhatian individu untuk mereka dan mengidentifikasi pelanggan tetap. Ukuran dalam dimensi ini adalah perhatian pribadi kepada klien, memenuhi kebutuhan mereka, jam kerja yang sesuai bagi pelanggan dan memperhatikan kepentingan terbaik bagi konsumen.

Pengembangan lima instrumen kualitas pelayanan menurut Parasuraman, et al., (Patel dan Amrita, 2014) adalah : (1) tangibles: penampilan fasilitas fisik dan materi disampaikan ke layanan. (2) reliability; kemampuan untuk melakukan layanan akurat dan menarik. (3) responsiveness: kemauan untuk membantu pelanggan dan memberikan layanan yang cepat. (4) assurance: kompetensi sistem dan keamanan, kredibilitas dan kesopanan. (5) empathy: kemudahan akses, didekati dan usaha yang diambil untuk memahami kebutuhan pelanggan.

\section{Metodologi Penelitian}

Penelitian ini menggunakan metode survei dengan teknik pengumpulan datanya: Populasi dalam penelitian ini adalah konsumen pada PT. Raden Auto Jakarta Penentuan ukuran sampel dalam penelitian dapat dilakukan berdasarkan beberapa cara. Menurut Isaac dan Michael (Sugiyono, 2010) memberikan tabel arahan penentuan jumlah sampel dari populasi, dengan tingkat kesalahan $1 \%, 5 \%$ dan $10 \%$. Makin besar jumlah sampel mendekati populasi, maka peluang kesalahan generalisasi semakin kecil dan sebaliknya makin kecil jumlah sampel menjauhi populasi, maka makin besar kesalahan generalisasi (diberlakukan umum). Teknik accidental sampling adalah teknik penarikan sampel secara kebetulan yaitu siapa saja yang kebetulan ditemui peneliti di lokasi penelitian (Supranto, 1997) Peneliti tidak menentukan siapa yang akan dijadikan responden, tetapi sampel yang diambil adalah dari individu yang kebetulan ditemui di lokasi penelitian dan dipan- dang individu tersebut cocok digunakan sebagai sumber data.

\section{Hasil Dan Pembahasan}

\section{Uji Asumsi Multikolineritas}

Pada penelitian ini uji multikolinearitas dilakukan untuk menguji apakah model regresi ditemukan adanya korelasi antar variabel bebas. Dapat dilihat dari Nilai Tolerance dan lawannya, Varian Inflation Factor (VIF). Jika nilai tolerance $<0,10$ atau $=$ nilai VIF $>10$ berarti menunjukkan adanya multikolinearitas (Ghozali, 2013). Berdasarkan hasil pengujian tidak terdapat variabel yang memiliki nilai VIF lebih besar dari 10 dan nilai tolerance yang lebih kecil dari $10 \%$, yang berarti bahwa tidak terdapat korelasi antar variabel bebas yang lebih besar dari 95\%. Maka dari hal itu dinyatakan tidak terdapat multikolinearitas antarvariabel bebas dalam model regresi.

Tabel 1: Uji Multikolineritas

\begin{tabular}{lcc}
\hline \multirow{2}{*}{ Variabel } & \multicolumn{2}{c}{ Collinearity Statistic } \\
\cline { 2 - 3 } & Tolerance & VIF \\
\hline Tangible & 0,685 & 1,459 \\
Emphaty & 0,417 & 2,399 \\
Assurance & 0,404 & 2,476 \\
\hline
\end{tabular}

\section{Uji Asumsi Heteroskedastisitas}

Pengujian ini bertujuan untuk menguji apakah dalam model regresi tidak terjadi kesamaan variance dari residual satu pengamatan ke pengamatan yang lain (Ghozali, 2013). berdasarkan hasil pengujian tersebut scatterplot diagram antara predicted value dengan residual.

Gambar 1 Uji Heteroskedastisitas

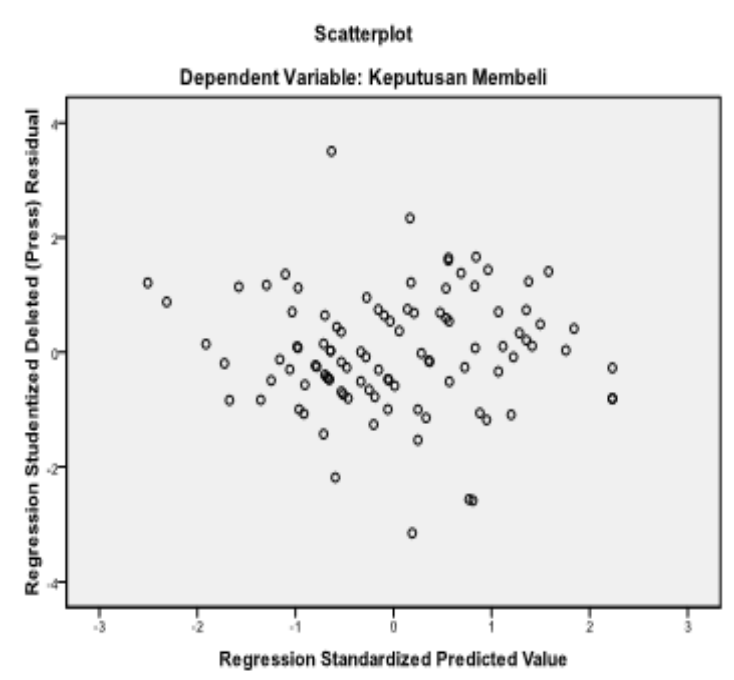




\section{Uji Asumsi Normalitas}

Pengujian normalitas data, dilakukan dengan dua cara yaitu dibuat histogram untuk distribusi standardized residual dan dibuat grafik normal probability plot pada setiap model. Untuk memperoleh hasil yang akurat

\section{Gambar 2 Normalitas Data}

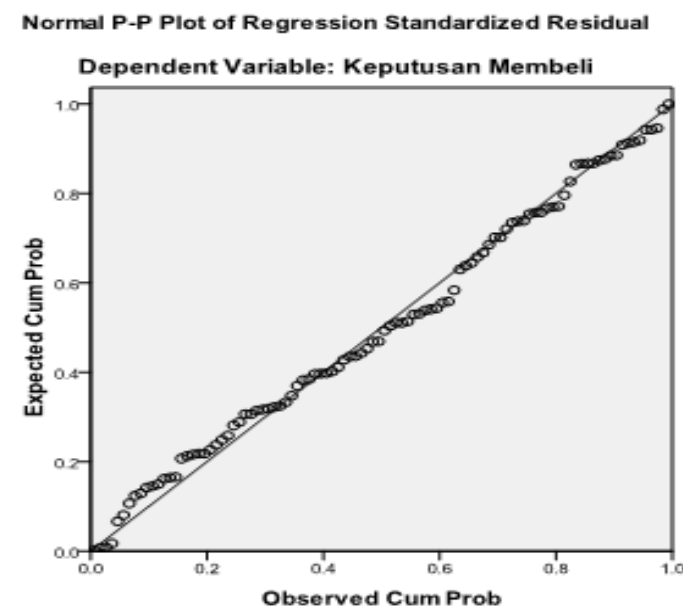

Pada gambar terlihat hasil penelitian pada uji asumsi normalitas data dengan Normal P-P Plot bahwa titik-titik data yang menyebar di sekitar garis diagonal dan penyebaran titik-titik data searah mengikuti garis diagonal, hal ini berarti data dalam penelitian ini memenuhi asumsi normalitas.

\section{Pengujian Hipotesis}

\section{Tangible (X1) Terhadap Keputusan Membeli (Y)}

Tabel 2 Regresi Linier Sederhana antara Tangible (X1) Terhadap Keputusan Membeli (Y)

\begin{tabular}{cccc}
\hline Model & $\beta$ & $\mathrm{t}_{\text {bitung }}$ & sig. \\
\hline Constant & 6,722 & & \\
Tangible & 0,833 & 9,924 & 0,000 \\
\hline
\end{tabular}

Dari perhitungan diatas diketahui regresi sederhana antara tangible (X1) terhadap keputusan membeli (Y) maka dapat diinterpretasikan bahwa ada model regresi yaitu : $\hat{Y}=6.722+0.833 \mathrm{X} 1$. Konstanta sebesar 6.722 menyatakan bahwa jika ada kenaikan nilai dari tangible (X1) maka keputusan membeli adalah 6.722. Koefisien regresi sebesar 0.833 menyatakan bahwa setiap penambahan nilai tangible maka akan memberikan kenaikan keputusan membeli sebesar 0.833 . Oleh karena $t_{\text {hitung }}>t_{\text {tabel }}(9.924>1.984)$ maka $\mathrm{H} 0$ ditolak dan $\mathrm{H} 1$ diterima, artinya secara parsial terdapat pengaruh yang signifikan antara tangible (X1) terhadap keputusan membeli (Y) pada PT. Raden Auto, Jakarta.

\section{Empathy (X2) Terhadap Keputusan Membeli (Y)}

Regresi sederhana antara empathy (X2) terhadap keputusan membeli (Y), dapat dilihat seperti pada tabel dibawah ini

Tabel 3 Regresi Linier Sederhana Antara Empathy (X2) Terhadap Keputusan membeli (Y)

\begin{tabular}{cccc}
\hline Model & $\beta$ & $\mathrm{t}_{\text {hitung }}$ & sig. \\
\hline Constant & 10,026 & & \\
Empathy & 0,739 & 11,031 & 0,000 \\
\hline
\end{tabular}

Dari perhitungan diatas diketahui regresi sederhana antara empathy (X2) terhadap keputusan membeli (Y) maka dapat diinterpretasikan bahwa ada model regresi yaitu : $\hat{Y}=10.026+0.739 X 2$. Konstanta sebesar 10.026 menyatakan bahwa jika ada kenaikan nilai dari empathy (X2) maka keputusan membeli adalah 10.026. Koefisien regresi sebesar 0.739 menyatakan bahwa setiap penambahan nilai empathy maka akan memberikan kenaikan keputusan membeli sebesar 0.739. Dengan nilai $t_{\text {hitung }}>t_{\text {tabel }}$ (11.031 > 1.984) maka H0 ditolak dan H1 diterima, artinya secara parsial terdapat pengaruh yang signifikan antara empathy (X2) terhadap keputusan membeli (Y) pada PT. Raden Auto, Jakarta.

\section{Assurance (X3) Terhadap Keputusan membeli (Y)}

Regresi sederhana antara assurance (X3) terhadap keputusan membeli (Y), dapat dilihat seperti pada tabel dibawah ini:

Tabel 4 Regresi Linier Sederhana Antara Assurance (X3) Terhadap Keputusan membeli (Y)

\begin{tabular}{cccc}
\hline Model & $\beta$ & $\mathrm{t}_{\text {hitung }}$ & sig. \\
\hline Constant & 9,485 & & \\
Assurance & 0,750 & 11,031 & 0,000 \\
\hline
\end{tabular}

Dari perhitungan diatas diketahui regresi sederhana antara assurance (X3) terhadap keputusan membeli (Y) maka dapat diinterpretasikan bahwa ada model regresi yaitu : $\hat{Y}=9.485+0.750 X 2$. Konstanta sebesar 9.485 menyatakan bahwa jika ada kenaikan nilai dari assurance (X3) maka keputusan membeli adalah 9.485. Koefisien regresi sebesar 0.750 menyatakan bahwa setiap penambahan nilai assurance maka akan memberikan kenaikan keputusan membeli sebesar 0.750, Oleh karena $t_{\text {hitung }}>t_{\text {tabel }}$ (12.084 > 1.984) maka H0 ditolak dan H1 diterima, artinya secara parsial terdapat pengaruh yang signifikan antara assurance $(X 3)$ terhadap keputusan membeli (Y) pada PT. Raden Auto, Jakarta. 
Tangible (X1), Empathy (X2), dan Assurance (X3) Terhadap Keputusan Membeli (Y)

Tabel 5 Regresi Linier Berganda antara Tangible (X1), Empathy (X2), dan Assurance (X3) Terhadap Keputusan membeli $(\mathrm{Y})$

\begin{tabular}{|c|c|c|c|}
\hline Model & $\beta$ & $\mathrm{F}_{\text {hitung }}$ & sig. \\
\hline Constant & $-3,798$ & \multirow{4}{*}{97,138} & \multirow{4}{*}{0,000} \\
\hline Tangible & 0,433 & & \\
\hline Empathy & 0,278 & & \\
\hline Assurance & 0,355 & & \\
\hline
\end{tabular}

Berdasarkan hasil perhitungan regresi pada tabel diatas, maka persamaan regresi tersebut adalah $\hat{Y}=$ $-3.798+0.433 \times 1+0.278 \times 2+0.355 X 3$. Dari hasil penelitian diketahui bahwa terdapat pengaruh signifikan antara tangible, empathy, dan assurance secara bersama-sama berpengaruh terhadap keputusan membeli Pada PT. Raden Auto, Jakarta. Hal ini berdasarkan hasil perhitungan uji $\mathrm{F}$, dimana diperoleh nilai $\mathrm{F}_{\text {hitung }}$ sebesar 97.138 dan $\mathrm{F}_{\text {tabel }}$ sebesar 2.698. Oleh karena Fhitung > Ftabel $(97.138>2.698)$, maka H0 ditolak dan $\mathrm{H} 1$ diterima, artinya ada pengaruh secara signifikan antara tangible (X1), empathy (X2), assurance $(X 3)$ secara bersama-sama terhadap keputusan membeli (Y). Berdasarkan hasil diatas maka dapat disimpulkan bahwa tangible, empathy, dan assurance secara bersama-sama berpengaruh terhadap keputusan membeli Pada PT. Raden Auto, Jakarta.

\section{Koefisien Determinasi}

Tabel 6 Sumary models

\begin{tabular}{ccc}
\hline Model & $\mathrm{R}$ & R Square \\
\hline 1 & 0,867 & 0,752 \\
\hline
\end{tabular}

Berdasarkan hasil perhitungan diperoleh hasil nilai korelasi antara tangible (X1), empathy (X2), dan assurance $(\mathrm{X} 3)$ terhadap keputusan membeli (Y) adalah sebesar 0.867 , atau berada pada kuadran 0.80 - 1.000 (Sugiyono, 2005), hal ini berarti pengaruh tangible (X1), empathy (X2), dan assurance (X3) terhadap keputusan membeli (Y) sangat kuat dan positif. Sedangkan nilai $\left(R^{2}\right)$ sebesar 0.752 atau $75.2 \%$, ini artinya variabilitas keputusan membeli yang terjadi disebabkan oleh tangible, empathy, dan assurance. Dengan kata lain bahwa pengaruh tangible (X1), empathy (X2), assurance (X3) terhadap keputusan membeli (Y) sebesar 75.2\%, sedangkan sisanya sebesar $24.8 \%$ dipengaruhi oleh faktor lain.

\section{Kesimpulan}

Setelah menguraikan dan membahas permasalahan, maka penulis berkesimpulan sebagai berikut: (1) Dari hasil penelitian diketahui terdapat pengaruh yang signifikan antara tangible terhadap keputusan membeli pada PT. Raden Auto, Jakarta. Hal ini berdasarkan hasil perhitungan uji hipotesis parsial, dimana diperoleh nilai $t_{\text {hitung }}$ sebesar 9.924 dan $\mathrm{t}_{\text {tabel }}$ sebesar 1.984, oleh karena $\mathrm{t}_{\text {hitung }}>\mathrm{t}_{\text {tabel }}(9.924>$ 1.984) maka H0 ditolak dan H1 diterima, artinya secara parsial terdapat pengaruh yang signifikan antara tangible (X1) terhadap keputusan membeli (Y) pada PT. Raden Auto, Jakarta, (2) Dari hasil penelitian diketahui terdapat pengaruh yang signifikan antara empathy terhadap keputusan membeli pada PT. Raden Auto, Jakarta. Hal ini berdasarkan hasil perhitungan uji hipotesis parsial, dimana diperoleh nilai $\mathrm{t}_{\text {hitung }}$ sebesar $11.031 \mathrm{dan}_{\text {tabel }}$ sebesar 1.984. Oleh karena $t_{\text {hitung }}>t_{\text {tabel }}(11.031>1.984)$ maka H0 ditolak dan H1 diterima, artinya secara parsial terdapat pengaruh yang signifikan antara empathy (X2) terhadap keputusan membeli (Y) pada PT. Raden Auto, Jakarta, (3) Dari hasil penelitian diketahui terdapat pengaruh yang signifikan antara assurance terhadap keputusan membeli pada PT. Raden Auto, Jakarta. Hal ini berdasarkan hasil perhitungan uji hipotesis parsial, dimana diperoleh nilai $t_{\text {hitung }}$ sebesar 12.084 dan $t_{\text {tabel }}$ sebesar 1.984. Oleh karena $t_{\text {hitung }}>t_{\text {tabel }}$ (12.084 > 1.984) maka H0 ditolak dan H1 diterima, artinya secara parsial terdapat pengaruh yang signifikan antara assurance (X3) terhadap keputusan membeli (Y) pada PT. Raden Auto, Jakarta, dan (4) Dari hasil penelitian diketahui terdapat pengaruh yang signifikan antara tangible, empathy, dan assurance secara bersama-sama berpengaruh terhadap keputusan membeli Pada PT. Raden Auto, Jakarta. Hal ini berdasarkan hasil perhitungan uji hipotesis berganda, dimana diperoleh nilai $\mathrm{F}_{\text {hitung }}$ sebesar 97.138 dan $\mathrm{F}_{\text {tabel }}$ sebesar 2.698. Oleh karena $\mathrm{F}_{\text {hitung }}>$ $\mathrm{F}_{\text {tabel }}(97.138>2.698)$, maka H0 ditolak dan H1 diterima, artinya ada pengaruh secara signifikan antara tangible (X1), empathy (X2), assurance (X3) secara bersama-sama terhadap keputusan membeli (Y). Berdasarkan hasil diatas maka dapat disimpulkan bahwa tangible, empathy, dan assurance secara bersama-sama berpengaruh terhadap keputusan membeli Pada PT. Raden Auto, Jakarta

\section{Saran}

Setelah menguraikan dan membahas permasalahan, maka penulis berkesimpulan bahwa dalam hal kualitas pelayanan, karyawan lebih dapat memperhatikan konsumen dengan penuh perhatian, seperti cepat tanggap terhadap keinginan atau kemauan yang konsumen butuhkan. Selain itu, pelayanan kualitas yang lebih ditingkatkan agar dapat memberikan hasil yang cukup efektif terhadap pembentukan keputusan pembelian sehingga perusahaan dapat memberikan inovasi yang terus menerus sehingga memberikan nilai lebih terhadap keputusan pembelian konsumen. 


\section{Referensi}

Aghdaie, S. F. Amiri dan F. Faghani. (2012). Mobile Banking Service Quality and Customer Satisfaction (Application of SERVQUAL Model). International Journal Management Business Research. Vol. 2 No. 4. pp. 351- 361

Arief, Sritua. (2006). Metodologi Penelitian Ekonomi. Jakarta: UI Press.

Bachler, Schoen D.D. (2004). Building brand loyalty through individual stock ownership. Journal Product Brand Management. Vol. 13 No. 7. pp. 488-497.

Bahraini, K, Shah Ali-Zadeh Kalkhuran, M. Nouraei, F. (2009). Evaluation of service quality in Islamic Azad University based on SERVQUAL and QFD models (A Case Study of Islamic Azad University, Aliabad Katoul branch. Management Research. Vol. 6, No. 14. pp. 62-79.

Bearman, Barry dan Evans, Joel R. (2002). Retail Management: A Strategic Approach, Ninth Edition. Prentice Hall: Englewood Cliffs.

Bolton, R.N., Anders Gustafsson, Janet McColl-Kennedy, Nancy Sirianni, David Tse. (2014). Small details that make big differences: a radical approach to consumption experience as a firm's differentiating strategy. Journal Service Management. Vol. 25, No. 2, pp. 253-274.

Brodie, M. J., Duncan, R., Vespignani, H., Solyom, A., Bitenskyy, V. and Lucas, C. (2005), Dose-dependent Safety and Efficacy of Zonisamide: A Randomized, Double-blind, Placebo-controlled Study in Patients with Refractory Partial Seizures. Epilepsia, Vol. 46, pp. 31-41. doi: 10.1111/j.0013-9580.2005.14704.x.

Ehsani, Mohammad. Hashem Kozechian, Ehsan Tatari Hassan Gaviar Sirus Jafari Zafar Abadi. (2014). The Comparison of Service Quality in Public and Private Clubs in Lorestan Province using SRERVQUAL Model. International Journal of Academic Research in Business and Social Sciences. Vol. 4, No. 12, pp. 434444. doi: 10.6007/IJARBSS/v4-i12/1374.

Esch, F., R., L. Tobias, S.H. Bernd and G. Patrick (2006). Are brands forever? How brand knowledge and relationships affect current and future purchases. Journal Product Brand Management. Vol. 15 No. 2. pp. 27-49.

Ghanbarpour, A. Saatchian, V. Pour Soltani Zarandi, H. (2012). The relationship between the culture of organizational learning, learning motivation and internal service quality in selected Federations. Journal of Sport Management. No. 14. pp. 56-76.

Ghozali, Imam. (2003). Analisis Multivanate Dengan Program SPSS. Edisi Ke 2. Semarang: Universitas Diponegoro.

Karimi, A.A. Makizadeh Vahid and Jamalieh Bastami, Behtash (2009). The relationship between service quality and customer loyalty in the commercial-service organizations. Journal of Management Vision. Vol. 9 No. 32. pp. 29-47.

Kotler, Philip dan Armstrong, Garry. (2008). Prinsip-Prinsip Pemasaran, Jilid 1. Jakarta: Erlangga.

Lupiyoadi, Rambat dan Hamdani (2008). Manajemen Pemasaran Jasa. Edisi 2, Jakarta: Salemba Empat.

Namin, Ardeshir Tajzadeh, Niko Pilevary and Aidin Tajzadeh Namin (2012). Measuring customer satisfaction using SERQUAL survey. Management Science Letters. Vol. 2. pp 933-938. doi: 10.5267/j.msl.2011.10.011.

Patel, N.K., and Amrita Singh. (2014). Customers' Perception Towards Service Quality Of Insurance Industry: A Study Conducted In Dehradun. Commonwealth Journal Of Commerce dan Management Research. Vol. 1 No. 4. pp. 64-72. 
Pourkiani, Masoud, Mehrdad Goudarzvand Chegini, Samin Yousefi and Shiva Madahian (2014). The Relationship between service Quality with Customer Satisfaction and words of mouth (Case study: Iran Insurance branch, Guilan). International Journal of Management and Humanity Sciences. Vol. 3 No. 6. pp. 2340-2350.

(2014). Service quality effect on satisfaction and word of mouth in insurance industry. Management Science Letters. Vol. 4. No. 8, pp. 1773-1780.

Rajagopal (2006). Consumer perspectives on brand extension effects in mexico: An empirical analysis of buying decision patterns. Latin America Business Review. Vol. 7 No. 1. pp. 99-118.

Redmond, W.H., 2000. Consumer rationality and consumer sovereignty. Review Social Econonomic. Vol. 58 No. 2. pp. 177-196.

Seyyed Javadin R dan Kimasi M (2005). Quality Management Services. Tehran: Neghah Danesh Publication.

Shah, Saad Hussain, Aziz, J., Jaffari, A. R., Waris, S., Ejaz, W., Fatima, M. dan Sherazi, S. K (2012). The Impact of Brands on Consumer Purchase Intentions. Asian Journal of Business Management. Vol. 4 No. 2. pp. 105-110.

Simamora, Bilson. (2003). Panduan Riset Perilaku Konsumen. Jakarta: Ramedia Pustaka Utama.

Sugiyono. (2010). Metode Penelitian Administrasi. Jakarta: Alfabeta.

Supranto. (1997). Metode Riset. Jakarta: Rinekacipta.

Sutisna. (2002). Perilaku Konsumen Dan Komunikasi Pemasaran. Bandung: Rosda Karya.

Swastha, Basu. (2000). Pengantar Bisnis Modern. Pengantar Ekonomi Perusahaan, Modern. Jakarta: Liberty.

Terrell, G.W. (2002). Social class influences on purchase evaluation criteria. Journal Consum. Mark. Vol. 19 No. 3. pp. 46-59.

Theodorakis, N. D., Alexandris, K., Tsigilis, N., dan Karvounis, S. (2013). Predicting spectators' behavioural intentions in professional football: The role of satisfaction and service quality. Sport Management Review. Vol. 16 No. 1. pp. 85-96.

Tjiptono, Fandy. (2008). Service Management Mewujudkan Layanan Prima. Yogyakarta: Andi.

Umar, Husein. (2005). Metode Penelitian. Jakarta: Salemba Empat. 
